\title{
IMPACT OF PHYSIOTHERAPEUTIC PROCEDURES ON THE TREATMENT OF DAMAGED ROTATOR CUFF MUSCULES OF THE SHOULDER GIRDLE
}

\author{
Akademia Wychowania Fizycznego we Wrocławiu, Poland

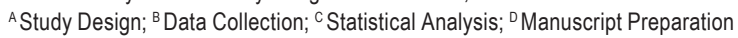 \\ Address for corpespondence: \\ Jagoda Walowska \\ Słoneczna 45, 55-010 Święta Katarzyna, Poland \\ E-mail: jagodawalowska@wp.pl
}

Bartosz Bolach, A, B, C Jagoda Walowska, , C, D Eugeniusz Bolach ${ }^{\text {A, B, D }}$

\begin{abstract}
Ahstract Damage to the rotator cuffs within the shoulder girdle is one of the many causes of the painful shoulder syndrome. The main symptom is the accompanying pain limiting partial or complete mobility in the shoulder joint. Weakness and atrophy of the deltoid and supraspinous muscles of the shoulder are secondary symptoms caused by immobilization of the upper limb. The aim of the study was to evaluate the effects of the use of physical therapy in women with damaged rotator cuff muscles of the shoulder girdle. The study involved 30 women aged $45-70$, who were divided into two groups: professionally active $(n=15)$ and professionally inactive $(n=15)$. The muscle strength of the shoulder joint rim, strength of the hand grip and pain assessment according to the VAS scale were analyzed. The assessment of upper limb fitness was assessed before and after 20 physiotherapy procedures. Professionally active women returned to physical fitness faster, gaining greater strength of the shoulder girdle, strength of the hand grip and reduction of perceptible pain.
\end{abstract}

Key Wordls tens currents, kinesiotherapy, Lovett scale, VAS scale, rotator cuff

\section{Introduction}

Damage to the rotator cuff muscles of the shoulder girdle (supraspinatus, infraspinatus, subscapularis, teres minor) is one of many causes of the painful shoulder. Muscle damage causes changes in joint biomechanics. Pain occurs mainly at night. It is difficult to perform everyday activities. Symptoms may be chronic or acute. There are four phases, different sizes of damage, including partial or total damage (Ślęzak, 2018; Clark, Harryman, 1992). The exact cause of the appearance of this dysfunction is not fully known. It is suspected that it may be the result of excessive tensile forces, degenerative changes and degenerative cone-building structures, subluxation or dislocation of the shoulder joint, joint inflammation, clavicle fracture, muscular weakness due to age, improper sports training and the associated occurrence joint overload, exposure to overload or long-term exercise in a static job position (Ault, 2002; Lesiak, 2002; Herberts, Kadefors, Högfors, Sigholm, 1984; Sobierajska-Rek, 2017). Imaging tests (including ultrasound, $\mathrm{X}$-ray, magnetic resonance) and physical examination of the patient are used in 
the diagnostics, which allows a more accurate determination of the site and degree of structural damage (Zanetti, Gerber, Hodler, 1998, Nakagaki, Ozaki, Tomita, Tamai, 1995; Dziak, 2003). The complaints are pain in the shoulder area of the shoulder joint rotator cuff, limited mobility and the associated limited self-service options and daily activities. The rehabilitation process includes both pharmacotherapy and physiotherapy, including kinesitherapy, physical therapy (electrotherapy - mainly TENS, laser therapy, local cryotherapy, ultrasounds, magnetotherapy), massage and balenotherapy. In the field of pharmacotherapy, calcitonin-based drugs, corticosteroids, GABA antagonists and sympatholytics, non-steroidal anti-inflammatory drugs and steroid injections are most commonly used. According to the recommendations (WHO), the use of pharmacotherapy in this dysfunction should be performed in accordance with a two-level scheme, including treatment from smaller to increased doses of the drug (Kujawa, Gawroński, Szyguła, Furgała, Janiszewski, 2003; Gawroński, 2003). The use of physiotherapy treatments allows to achieve the full range of mobility, prevents the reduction of strength and muscle mass, motivates for further rehabilitation. It affects psychophysical abilities, improves the perceived quality of life. The procedure of motor rehabilitation after rotator cuff injury includes counter-factorial exercises, isometric exercises in closed kinematic chains, passive unloading on the CPM rail, active exercises, active resistance, passive movements, dynamic shoulder rehabilitation exercises, general developmental exercises. It is possible to use neurophysiological methods, such as PNF (Czamara, 2003, Demkiewicz, Krawiec, Hendzelek, 2015; Rotter, Mosiejczuk, Żugaj, Ptak, Lubińska, 2005). One of the supporting methods is kinesiology taping. Unfortunately, sometimes conservative procedures are not enough. When the taper of the rotator muscle is completely ruptured, it is necessary to perform a surgical procedure. Only then physiotherapeutic and pharmacological activities are implemented. The prognosis depends on many factors, such as the age of the patient, the degree of structural damage, the speed of assistance and the implementation of treatment. The healing process is additionally hampered by nerve damage that causes progressive muscular atrophy. Reoperation is sometimes required (Albritton, Graham, Richards, Basamania, 2003; Gerber, Fuchs, Hodler, 2000; Cofield, 1982; Bigliani, Cordasco, Mcllveen, Musso, 1992; Post, Silver, Singh, 1983). A person who has had a rotator cuff muscle disease should remember that he is exposed to a joint re-sprain. Most often this occurs within two years from the end of treatment of the previous injury, when the cause of joint instability has not been established (Bartoft, 2002). That is why prevention and appropriately selected physical activity are so important. It happens that the patient will be forced to change the nature of work (Gore, Murray, Sepic, Gardner, 1986).

\section{Aim of the study}

The aim of the study was to assess the effect of therapeutic effects after the application of physiotherapeutic procedures in the damage of damaged rotator cuff muscules of the shoulder girdle in two groups of professionally active and inactive women.

\section{Research questions}

1. Do women professionally active return to physical fitness faster than professionally inactive women after damage to the rotator cuff muscles of the shoulder girdle?

2. Do physiotherapeutic treatments reduce the pain of the shoulder girdle in women after damage to the rotator cuff? 
3. Did the physiotherapy treatments increase the strength of the shoulder girdle muscle and the strength of the hand grip?

\section{Material of research}

The examination of women after damage to the cone of the rim of the shoulder girdle was performed at the Center of Occupational Medicine in Legnica in the Department of Rehabilitation in December 2016 and January 2017. 30 women aged between 45 and 70 joined the study. The average age was 58.6. 15 women were professionally active (average age -52.7 ) and 15 were professionally inactive (mean age - 64.5). The average age of inactive women was higher than the average age of active women and this difference was statistically significant.

\section{Test method}

The work assessed the strength of the shoulder muscles of the shoulder joint with the Lovett test with movements of bending, straightening, abduction and restoration as well as the strength of the hand grip with the Collins force gauge. The VAS scale was used to assess the pain. The examinations of the efficiency of the upper limb after damage to the rotator cuff were performed at the beginning of the therapeutic improvement and after 20 treatments. In both groups, the test and control, the same physiotherapeutic treatments were used: TENS currents, laser, ultrasounds, local cryotherapy and kinesiotherapy.

\section{Methods of statistical analysis}

Distributions of the analyzed features were presented by determining the following parameters: arithmetic mean, standard deviation and range of variation (minimum and maximum value). Changes in the mean values of the measured values were evaluated using Student's t-test for dependent samples. Group comparisons were conducted using Student's t-test for independent trials. The statistical significance assessment was determined at the significance level of $p<0.05$. The calculations were made using the STATISTICA 12 package from Stat.Soft (Ferguson, Takane, 1997; Stanisz, 2007).

\section{Results}

Analysis of pain perception:

The physiotherapy treatments applied in both groups led to a reduction in the intensity of pain. The average level of pain assessed on the VAS scale decreased after surgery in the group of active women by 1.6 and this change was statistically significant. In the group of inactive women, the mean decrease in perceived pain was 1.1 on the VAS scale and was not statistically significant $(p=0.069 ; p>0.05)$. The greater effectiveness of the treatments used in the group of active women is emphasized by the fact that in this group the reduction in pain was noted in $87 \%$ of the subjects and there were no cases of pain. In contrast, in the group of inactive women, pain reduction occurred in $67 \%$ of subjects, and in $27 \%$ there was an increase in pain experienced despite physiotherapy (Table 1 ). 
Table 1. Evaluation of the statistical significance of changes in the level of perceived pain after physiotherapy in a group of active and inactive women

\begin{tabular}{|c|c|c|c|c|c|c|c|}
\hline \multirow{3}{*}{ Group } & \multicolumn{5}{|c|}{ Pain in the VAS scale } & \multirow{2}{*}{\multicolumn{2}{|c|}{ Student's test }} \\
\hline & \multicolumn{2}{|c|}{ before treatments } & \multicolumn{2}{|c|}{ after treatments } & \multirow{2}{*}{$\begin{array}{l}\text { average } \\
\text { change }\end{array}$} & & \\
\hline & average & stand. dev. & average & stand. dev. & & $t$ & $P$ \\
\hline Professionally active & 5.5 & 2.4 & 3.9 & 2.5 & -1.6 & 5.87 & $<0.001$ \\
\hline Professionally inactive & 5.4 & 2.2 & 4.3 & 2.2 & -1.1 & 1.97 & 0.069 \\
\hline
\end{tabular}

Analysis of hand grip strength:

Physiotherapy performed in the majority of women surveyed led to increased strength of the hand grip. In the group of professionally active women, the increase in hand strength was found in $93 \%$ of the subjects $(n=14)$, and in $7 \%(n=1)$ the strength of the grip decreased despite the improvement process. In turn, in the group of inactive women, the increase in hand strength occurred in $60 \%$ of the respondents $(n=9)$, in $3 \%$ remained unchanged, while in $27 \%(n=4)$ the strength of hand grip decreased despite treatments. The average changes in hand grip strength after the treatments were higher in the group of active than inactive women, and the change in the average value of hand grip strength after treatments was statistically significant in the group of statistically active women, and statistically insignificant in the group of inactive women $(p=0.105 ; p>0.05)$ (Table 2).

Table 2. Evaluation of statistical significance of changes in hand grip strength after physiotherapy in a group of active and inactive women

\begin{tabular}{|c|c|c|c|c|c|c|c|}
\hline \multirow{3}{*}{ Group } & \multicolumn{5}{|c|}{ Hand strength (kG) } & \multirow{2}{*}{\multicolumn{2}{|c|}{ Student's test }} \\
\hline & \multicolumn{2}{|c|}{ before treatments } & \multicolumn{2}{|c|}{ after treatments } & \multirow{2}{*}{$\begin{array}{l}\text { average } \\
\text { change }\end{array}$} & & \\
\hline & average & stand. dev. & average & stand. dev. & & $t$ & $p$ \\
\hline Professionally active & 16.1 & 8.5 & 20.3 & 9.2 & 4.3 & 4.41 & $<0.001$ \\
\hline Professionally inactive & 11.6 & 6.0 & 14.0 & 6.5 & 2.4 & 1.74 & 0.105 \\
\hline
\end{tabular}

Analysis of the assessment of the strength of the shoulder girdle muscles:

Paddle muscle:

Applied physiotherapy treatments resulted in an increase in the strength of the deltoid muscle in $87 \%$ of the examined women in the group of professionally active women $(n=13)$ and in $47 \%$ of women in the group of professionally inactive $(n=7)$. Among active women, there were no cases of decrease in subs by mice, while in the group of inactive women there were two such cases $(n=2)(13 \%)$. Strength of the subscapular muscle assessed by the Lovett test increased on average after treatments in both groups of women examined. The increase in the mean subscapular muscle strength after surgery was clearly higher in the group of professionally active women. The mean value of the subscapular muscle increase after surgery was 0.9 points on the Lovett scale in the group of professionally active women and was statistically significant. In the group of inactive women, the mean change in strength of this muscle was three times smaller and was not statistically significant. 
The trapezius muscle and the oblong smaller muscle:

There were no effects of the applied physiotherapeutic treatments on the strength of the trapezius and oblong muscles in both groups of the studied women. The assessment of the strength of these muscles with the Lovett test before and after the treatments was the same. Only the mean value of the Lovetta strength score was in the group of professionally active women slightly higher than the average in the group of professionally inactive women, but the mean values in both groups did not differ significantly in terms of statistics.

Supraspinatus muscle:

In turn, the applied physiotherapeutic treatments contributed to the increase of the supraspinatus muscle assessed by the Lovett test. In the group of professionally active women the strength of this muscle increased in all individuals by 1 point in the Lovett scale, while in the group of professionally inactive women the increase in supraspinous muscle was observed in only $53 \%$ of subjects $(n=8)$. There have been no reports of a reduction in the strength of this muscle after the procedures. The mean increase in supraspinous muscle strength in the group of professionally active women was statistically significantly higher $(p=0.002 ; p<0.05)$ than the average increase in muscle strength in the group of professionally inactive women.

\section{Discussion}

One of the reasons that make it difficult to assess muscle strength when it comes to damage to the rotator cuff muscles of the shoulder girdle pain is a concomitant significantly disturbing the function of the shoulder joint and limiting the range of motion in the limb. The reduction in the range of active movements was particularly noticeable. The changes that occur within the muscles: supraspinous, infraspinous, minor and subscapular muscles, can arise through micro-injuries and overloads, or through so-called indirect mechanism. The occurrence of pain at night is characteristic for this disease. J. Kuhn (2009), after analyzing the available literature, noted that performing exercises in the treatment of damaged rotator cuff results in a significant reduction in the occurrence of pain and improvement of general functioning. The type of physiotherapeutic treatments and exercises used in the rehabilitated process should be selected individually (Horrigan, Shellock, Mink, Deutsch, 1999). P.D. McCann, M.E. Wootten, M.P. Kadaba, L.U. Bigliani (1993) emphasize the important role of isometric exercises and resistance during rehabilitation. According to these researchers, these exercises contribute the most to improving both well-being and improving the functional state of the limb. M. Decker, J. Tokish, H. Ellis, M. Torry, R. Hawkins (2003) emphasize that during rehabilitation one should take into account not only the place, the extent of structural damage and the degree of dysfunction, but also what functions the individual muscles perform. R. Hughes (1996) in his research emphasized that in the training of muscles involved in the construction of the rotator cuff, the internal rotation of the joint should be limited. P. Millett, R. Wilcox, J. O'Holleran, J. Warner (2006) described in detail four stages of recovery in patients undergoing surgical treatment of damaged shoulder joint structures. The overall goal of rehabilitation is to return to the full range of mobility in the joint and strengthen muscles, which will additionally serve as a protective function against further injuries to joint structures. Rehabilitation should be carried out gradually. Initially, it should be run to a limited extent. The therapy will focus on improving flexibility and increasing the strength and durability of the muscles building the shoulder girdle and those muscles responsible for the mobility of the spatula. In the final stage of rehabilitation, the entire muscular corset, including postural muscle, should be strengthened to improve overall muscle performance and strength (Jobe, Moynes, Brewster, 1987). Many researchers deal with issues related to 
therapeutic rehabilitation and optimization of the process of rehabilitation of patients who have suffered muscle trauma to the rotator cuff. Unfortunately, the complexity of the issue, the multifaceted clinical picture, the variety of symptoms and accompanying symptoms makes this issue still very problematic and there is a need to develop newer and better programs for improving and implementing prophylaxis (Ainsworth, 2006).

The research results indicate that the professionally active people returned more efficiently to greater efficiency. Applied physiotherapy in both groups reduced pain, which promoted the improvement of the quality of life and at the same time encouraged to continue to attend rehabilitation, motivated to take further therapeutic measures. The analgesic effects in both groups were satisfactory, but not all the patients had the desired effect. At the same time, it can be stated that well-chosen treatments can have an impact on accelerating the healing process. Early correct diagnosis and treatment increases the likelihood of a positive treatment effect.

\section{Conclusions}

1. It was found that professional activity and the use of appropriate physiotherapeutic treatments have a huge impact on the progress of the process of improving the upper limb after injury of the rotator cuff of the shoulder girdle in women.

2. The physiotherapy treatments applied in both groups reduced the intensity of pain and this change was statistically significant in professionally active women.

3. Professionally active women returned to physical fitness faster than less active.

4. The muscle strength of the shoulder girdle and hand grip was higher in professionally active peers.

\section{References}

Ainsworth, R. (2006). Physiotherapy rehabilitation in patients with massive, irreparable rotator cuff tears. Musculoskeletal Care, 4 (3), $140-151$

Albritton, M., Graham, R., Richards, II R.S., Basamania, C. (2003). An anatomic study of the effects on the suprascapular nerve due to retraction of the supraspinatus muscle after a rotator cuff tear. Journal of Shoulder and Elbow Surgery, 12 (5), 497-500.

Ault, J. (2002). Zespół cieśni podbarkowej. Rehab Med., 6, 26-33.

Bartoft, E. (2002). Zespół bolesnego barku z punktu widzenia fizjoterapeutycznego - przegląd literatury. Reh. Med., 6, 52-80.

Bigliani, L.U., Cordasco, F.A., Mcllveen, S.J., Musso, E.S. (1992). Operative treatment of failed repairs of the rotator cuff. The Journal of Bone and Joint Surgery. American Volume, 74 (10), 1505-1515.

Clark, J.M., Harryman, D.T. (1992). Tendons, ligaments, and capsule of the rotator cuff. Gross and microscopic anatomy. The Journal of Bone and Joint Surgery. American Volume, 74 (5), 713-725.

Cofield, R.H. (1982). Subscapular muscle transposition for repair of chronic rotator cuff tears. Surgery, Gynecology \& Obstetrics, 154 (5), 667-672.

Czamara, A. (2003). Program fizjoterapii po zwichnięciach przednich stawu ramiennego. Med. Sportiva, 7 (2), 139-150.

Decker, M., Tokish, J., Ellis, H., Torry, M., Hawkins, R. (2003). Subscapularis Muscle Activity during Selected Rehabilitation Exercises. The American Journal of Sports Medicine, 31 (1), 126-134.

Demkiewicz, D., Krawiec, D., Hendzelek, A. (2015). Uwzględnienie treningu motorycznego w rehabilitacji zespołu cieśni podbarkowej. Praktyczna Fizjoterapia i Rehabilitacja, 63, 34-38.

Dziak, A. (2003). Zasady diagnostyki zespołu bolesnego barku. Med. Sportiva, 7 (2), 81-92.

Ferguson, A.G., Takane, Y. (1997). Analiza statystyczna w psychologii i pedagogice. Warszawa: Wydawnictwo Naukowe PWN.

Gawroński, W. (2003). O krioterapii raz jeszcze. Med. Sportiva, 7 (2), 155.

Gerber, Ch., Fuchs B., Hodler, J. (2000). The Results of Repair of Massive Tears of the Rotator Cuff. JBJS, 82 (4), 505. 
Gore, D.R., Murray, M.P., Sepic, S.B. (1986). Gardner G.M. Shoulder-muscle strength and range of motion following surgical repair of full-thickness rotator-cuff tears. The Journal of Bone and Joint Surgery. American Volume, 68 (2), 266-272.

Herberts, P., Kadefors, R., Högfors, C., Sigholm, G. (1984). Shoulder pain and heavy manual labor. Clinical Orthopaedics and Related Research, 191, 166-178.

Horrigan, J.M., Shellock, F.G., Mink, J.H., Deutsch, A.L. (1999). Magnetic resonance imaging evaluation of muscle usage associated with three exercises for rotator cuff rehabilitation. Medicine and Science in Sports and Exercise, 31 (10), 1361-1366.

Hughes, R. (1996). Force Analysis of Rotator Cuff Muscles. Clinical Orthopaedics and Related Research, 330, 75-83.

Jobe, F.W., Moynes, D.R., Brewster, C.E. (1987). Rehabilitation of shoulder joint instabilities. The Orthopedic Clinics of North America, $18(3), 473-482$.

Kuhn, J. (2009). Exercise in the treatment of rotator cuff impingement: A systematic review and a synthesized evidence-based rehabilitation protocol. Journal of Shoulder and Elbow Surgery, 18 (1), 138-160.

Kujawa, J., Gawroński, W., Szyguła, Z., Furgała, W., Janiszewski, M. (2003). Wybrane metody terapii fizykalnej w rehabilitacji chorych po urazach barku. Med. Sportiva, 7, 125-135.

Lesiak, A. (2002). Zespół bolesnego barku - patogeneza, obraz kliniczny i leczenie. Rehabilitacja Medyczna, 6, 26-43.

McCann, P.D., Wootten, M.E., Kadaba, M.P., Bigliani, L.U. (1993). A kinematic and electromyographic study of shoulder rehabilitation exercises. Clinical Orthopaedics and Related Research, 288, 179-188.

Millett, P., Wilcox, R., O'Holleran, J., Warner, J. (2006). Rehabilitation of the Rotator Cuff: An Evaluation-Based Approach. Journal of the American Academy of Orthopaedic Surgeons, 14 (11), 599-609.

Nakagaki, K., Ozaki, J., Tomita, Y., Tamai, S. (1995). Function of supraspinatus muscle with torn cuff evaluated by magnetic resonance imaging. Clinical Orthopaedics and Related Research, 318, 144-151.

Post, M., Silver, R., Singh, M. (1983). Rotator cuff tear. Diagnosis and treatment. Clinical Orthopaedics and Related Research, 173, 78-91.

Rotter, I., Mosiejczuk, H., Żugaj, J., Ptak, M., Lubińska, A. (2005). Assessment of the influence of selected kinesitherapeutic methods on the function of the shoulder girdle in patients with the shoulder impingement syndrome. Journal Of Public Health, Nursing And Medical Rescue, 1, 65-72.

Sobierajska-Rek, A. (2017). Uszkodzenia stożka rotatorów w podeszłym wieku. Rehabilitacja pooperacyjna i w leczeniu zachowawczym. In: M. Podgórska (red.), Choroby XXI wieku - wyzwania w pracy fizjoterapeuty (pp. 9-29). Gdańsk: WSZ.

Stanisz, A. (2007). STATISTICA Stat.Soft. Kraków.

Ślęzak, M. (2018). Zespół bolesnego barku. Praktyczna Ortopedia I Traumatologia, 9, 38-46.

Zanetti, M., Gerber, Ch., Hodler, J. (1998). Quantitative assessment of the muscles of the rotator cuff with magnetic resonance imaging. Investigative Radiology, 13 (3), 163-170.

Cite this article aS: Bolach, B., Walowska, J., Bolach, E. (2019). Impact of Physiotherapeutic Procedures on the Treatment of Damaged Rotator Cuff Muscules of the Shoulder Girdle. Central European Journal of Sport Sciences and Medicine, 3 (27), 17-23. DOI: 10.18276/cej.2019.3-02. 